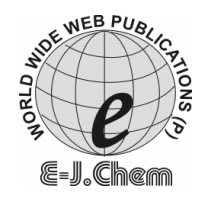

http://www.e-journals.net
ISSN: 0973-4945; CODEN ECJHAO

E-Journal of Chemistry

2009, 6(1), 77-88

\title{
Investigation of Hopanoid Biomarkers in Lake Sediments by GC-MS and RP-HPLC-APCI-MS
}

\author{
GAMZE KAVRAN BELIN \\ University of Geneva, Chemistry Department, \\ Laboratory of Mass Spectrometry, \\ Boulevard d'Yvoy 16, CH-1221 Geneva-4, Switzerland. \\ g.belin@pci.unizh.ch
}

Received 14 July 2008; Accepted 10 August 2008

\begin{abstract}
Hopanoids are mainly derived from bacteriohopanpolyols that occur especially in bacteria, show the importance of bacterial lipid contributions in geological materials. In this work, GC-MS and RP-HPLC-APCI-MS analyses of hopanoid biomarkers in oxic and anoxic sediment samples from Lake Cadagno (Swiss Alps) and Lake Voua de la Motte (Haute Savoie, France) are presented and discussed. Samples were ultrasonically extracted, fractionated by flush chromatography on silica gel and derivatised before the analyses. Periodic acid/ sodium borohydride cleavage was used to identify highly functionalised hopanoids.
\end{abstract}

Keywords: Hopanoids, Bacteriohopanetetrol, Biomarkers, Sediment, Lake Cadagno, Lake Voua de la Motte

\section{Introduction}

Hopanoids, whose primary function is to improve plasma membrane fluidity in prokaryotes, are in important class of biological markers. They are mainly derived from bacteriohopanepolyols which occur especially in bacteria and their presence in geological materials shows the importance of bacterial lipid contrubutions. As hopanoids are very stable and are not easily degraded, they are receiving an intense attention as biological markers with applications for geochemical studies of petroleum source, rocks and oils. Different bacterial groups possess recognizable biohopanoid distributions, giving hopanoids marker potential for specific bacterial populations and environmental conditions. Biohopanoids occur in several higher plants, ferns, mosses, fungi, protists, and particularly in bacteria ${ }^{1,2}$. The characteristic base structure of bacteriohopanols is given in Figure 1. Bacteria is the only known source of C35 hopanepolyols (bacteriohopanepolyols; BHPs), which is thought to act as cell membrane rigidifiers analogues to sterols in eukaryotes. 
Hopanoids are most abundant in aerobic bacteria (methanotrophs, heterotrophs and cyanobacteria), but they also occur in some anaerobic bacteria, but not in Archaea or eukaryotes $^{3}$. Hopanoids are divided into two groups, biohopanoids such as bacteriohopanetetrol (BHT) and geohopanoids such as hopanols, hopanoic acids and hopanes. It is known that the death of bacteria causes the formation of geohopanoids from biohopanoids by the diagenetic processes modifying the side chain structure.

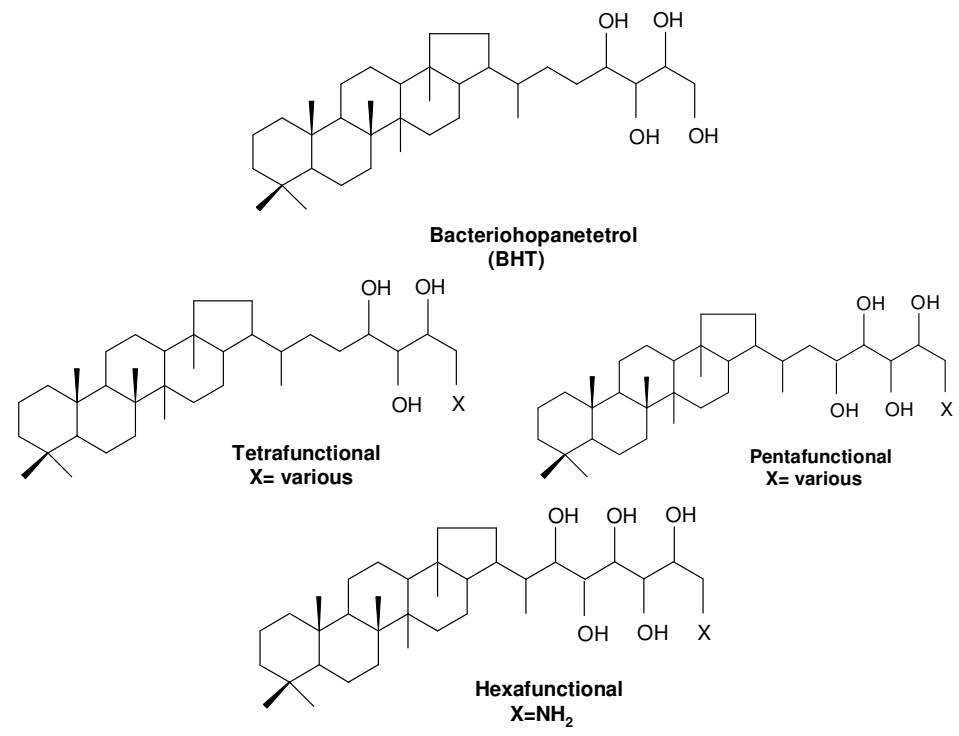

Figure 1. The characteristic base structure of bacteriohopanols.

In our research group various research subjects including $\mathrm{C}_{29}$-steroid detection in complex sedimentary ${ }^{4}$, aromatic stereoids in recent sediments ${ }^{5}$, carboxylic acids 6 , sedimentary occurrence of chlorophyllone ${ }^{7}$, steryl chlorin esters ${ }^{8}$ and tetrapyrolic pigments ${ }^{9}$ have already been studied in detail with diver's sediment samples.

The objective of this study is to analyse hopanoid biomarkers, which is a growing area of interest for the potential wealth of information they can provide relating to bacterial populations and important biogeochemical processes, from oxic and anoxic sediment samples of Lake Cadagno (valley of Piora, Swiss Alps) and Voua de la Motte (Haute Savoie, France). For this aim, hopanoids were initially extracted from sediment samples and derivatised for GCMS and RP-HPLC-APCI-MS analyses because of their high polarity and molecular weight. Periodic acid/sodium borohydride cleavage was used to convert them to more easily analysable terminal alcohols (Figure 2). Bacteria Zymomonas Mobilis was cultivated and purified for the BHT (bacteriohopanetetrol) identification in sediment samples. Distribution differences of identified hopanoids in oxic and anoxic zone are discussed.

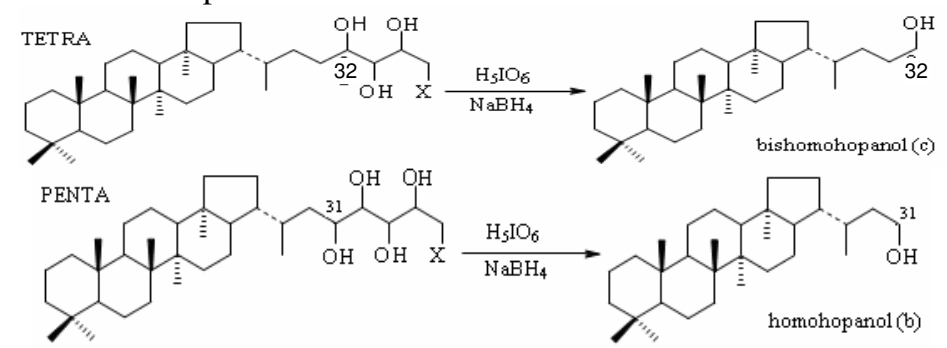




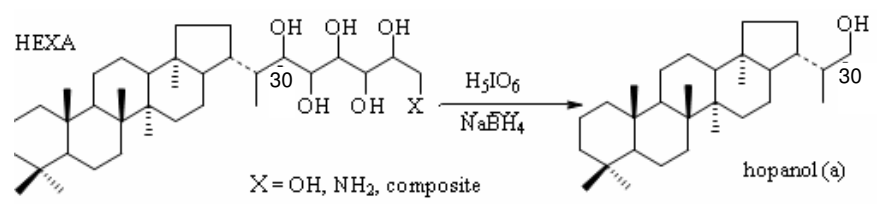

Figure 2. Periodic acid/sodium borohydride cleavage products.

\section{Experimental}

\section{Sediment sampling}

Sediment samples were collected from two lakes; Lake Cadagno and Voua de la Motte. Lake Cadagno is located at an altitude of $1920 \mathrm{~m}$ in the valley of Piora (Swiss Alps). This meromictic lake $\left(365.500 \mathrm{~m}^{2}\right.$, maximum water depth of $\left.21 \mathrm{~m}\right)$, is fed by surface waters with a low salt content and by sub aquatic spring waters rich in sulfate due to the dissolution of surrounding dolomites and gypsum. The density contrast between the two water inputs, together with the wind-protected setting and the presence of an ice cover for ca. 6 months per year, results in a highly stable water column through the year. These conditions favor the formation of a permanent anoxic zone that extends within the water column, at a depth of 10-12 m below the water surface. Sediment samples were collected from a depth of $21 \mathrm{~m}$ toward the center of the lake in winter 2005. This sampling depth was chosen so as to remain in the anoxic layer of the lake at all times. For the oxic zone studies, sediment samples were collected from a depth of $8 \mathrm{~m}$ of the same lake. The water was collected into glass bottles either by a peristaltic pump (250 $\mathrm{mL} / \mathrm{min}$ ) or by using a Plexiglas column with pneumatic closures. The sample bottles were brought back to the laboratory where they were agitated to resuspend any sedimented material. Half of the water was centrifuged $2 \mathrm{~h}$ at $4000 \mathrm{rpm}$, and half was left to sediment for $2 \mathrm{~h}$ to remove the largest particles. The samples were immediately frozen and stored at $-20^{\circ} \mathrm{C}$.

Lake Voua de la Motte is located at an altitude of $595 \mathrm{~m}$ near Thonon (Haute Savoie, France). This small eutrophic lake $\left(8300 \mathrm{~m}^{2}\right.$, maximum water depth of $\left.10 \mathrm{~m}\right)$, is fed only by streaming water and rainwater or by ground water. The density contrast between the two water inputs results in stratification of the lake. The highly mineralized deep layers do not mix with surface rainwater. This stratification as well as a very high tropic level favors the formation of a permanent anoxic zone that extends within the water column, at a depth of around $5 \mathrm{~m}$ below the water surface. Sediment samples from this lake were collected from the deepest point of the lake $(9 \mathrm{~m})$ and the same procedure as described above was applied for the sample storage.

\section{Sample preparation}

Sediment samples were lyophilized and the dried aliquots $(10 \mathrm{~g})$ were extracted ultrasonically in dichloromethane $(4 \times 150 \mathrm{~mL})$ and acetone $(3 \times 150 \mathrm{~mL})$. Final extract was SPE fractionated with $\mathrm{NH}_{2}$ cartridge and neutrals were separated from acidic compounds with $\mathrm{MeOH} / \mathrm{CHCl}_{3}(1: 4 \mathrm{v} / \mathrm{v}, 20 \mathrm{~mL})$. The fraction including neutrals and elementary sulphur was introduced to a copper column $(1.5 \mathrm{~cm} \times 12 \mathrm{~cm})$ in order to eliminate elementary sulphur from the sample. Sulphur free sample was introduced to a silica gel column $\left(3 \mathrm{~g} \mathrm{SiO}_{2}\right.$ with 240 400 mesh, $20 \mathrm{~cm} \times 6 \mathrm{~mm}$ ) in order to separate the target sample group including hopanoids. The aliphatic hydrocarbon fraction was eluted first with hexane $(20 \mathrm{~mL})$. Second fraction containing aromatic hydrocarbons was eluted with hexane/toluene $(3: 2 \mathrm{v} / \mathrm{v}, 20 \mathrm{~mL})$, polar intermediates containing third fraction was eluted with hexane/acetone/ MeOH (93:5:2 v/v/v; $30 \mathrm{~mL})$, sterols were eluted with the same elution solvent mixture as in the third fraction and finally more polar compounds containing hopanoids were eluted with $\mathrm{MeOH} / \mathrm{CHCl}_{3}(1: 4 \mathrm{v} / \mathrm{v}, 25 \mathrm{~mL})$. Sample preparation diagram is shown in Figure 3. Injection samples were acetylated for GC-MS and RP- 
HPLC-APCI-MS analyses. Acetylation of hopanols was achieved by using the method of Innes et $a l^{10}$. An aliquat of the sample was warmed to $50^{\circ} \mathrm{C}$ for $1 \mathrm{~h}$ with acetic anhydride/pyridine (4 $\mathrm{mL}, 1: 1 \mathrm{v} / \mathrm{v}$ ) and acetylated overnight at room temperature. The derivatized extracts were mixed with $5 \mathrm{~mL} \mathrm{H}_{2} \mathrm{O}$ for $1 \mathrm{~h}$ then the sample was transferred into the extraction balloon and 3 portions of $10 \mathrm{~mL} \mathrm{CH}_{2} \mathrm{Cl}_{2}(\mathrm{~d}=1,306)$ were added , mixed and pyridine $(\mathrm{d}=0,978)$ (top layer) was removed. The bottom layers were collected and finally transferred into the extraction balloon and saturated $\mathrm{NaHCO}_{3}$ was added carefully to remove $\mathrm{CO}_{2}$. Collected bottom layers (organic phase) were evaporated to near dryness and blown down under nitrogen before being weighted. Final product was dissolved in $100 \mu \mathrm{L}$ ethyl acetate. $50 \mu \mathrm{L}$ of TMS and then $50 \mu \mathrm{L}$ of this sample were taken into the same syringe, put into a glass vial and heated to $80^{\circ} \mathrm{C}$ for $1 \mathrm{~h}$ before the GC-MS analyses. On the other hand, periodic acid and sodium borohydride treatment was applied to convert bacteriohopanpolyols and composite hopanoids to more easily analyzable terminal alcohols. The sample was stirred at room temperature for $1 \mathrm{~h}$ with $300 \mathrm{mg}$ of $\mathrm{H}_{5} \mathrm{IO}_{6}$ in $\mathrm{THF} / \mathrm{H}_{2} \mathrm{O}$ $(4: 1 \mathrm{v} / \mathrm{v}, 3 \mathrm{~mL})$. After addition of $10 \mathrm{~mL}$ water, the mixture was extracted with petroleum ether $(15 \mathrm{~mL} \times 3)$. The combined extracts were rotary evaporated and residual water was removed by further evaporation as an azeotropic mixture with acetone. The final extract was stirred with $100 \mathrm{mg} \mathrm{NaBH} \mathrm{H}_{4}$ and $3 \mathrm{~mL} \mathrm{EtOH}$ under room temperature for $1 \mathrm{~h}$ to produce terminal alcohols. After the addition of $15 \mathrm{~mL}, 0.1 \mathrm{M}^{\text {of }} \mathrm{KH}_{2} \mathrm{PO}_{4}$, the mixture was extracted with ether $(15 \mathrm{~mL} \times 3)$. Collected fractions were combined, evaporated to near dryness and then the acetylation step was applied as explained before. Cleavage products were identified by GC-MS analyses.

\section{Cultivation of zymomonas mobilis}

Zymomonas mobilis (DSMZ products, Germany) which is a fermentative Gram-negative bacterium and the source for bacteriohopanols was cultivated for the BHT identification in sediment samples. Z. mobilis was grown semi-anaerobically at $30^{\circ} \mathrm{C}$. The solid medium was prepared with $4.0 \mathrm{~g}$ glucose $(2 \% \mathrm{w} / \mathrm{v}), 2.0 \mathrm{~g}$ yeast extract $(1 \% \mathrm{w} / \mathrm{v}), 3.0 \mathrm{~g}$ agar $(1.5 \% \mathrm{w} / \mathrm{v})$ in 200 $\mathrm{mL} \mathrm{H}_{2} \mathrm{O}$ to maintain the bacterium. The liquid medium was prepared with $4.0 \mathrm{~g}$ glucose $(2 \% \mathrm{w} / \mathrm{v})$, 2.0 g yeast extract $(1 \% \mathrm{w} / \mathrm{v}), 0.4 \mathrm{~g} \mathrm{KH}_{2} \mathrm{PO}_{4}(0.2 \% \mathrm{w} / \mathrm{v})$ at $\mathrm{pH} 6.0$ to grow the bacterium (11). After the sterilization of all solid and liquid mediums for 75 min under $165^{\circ} \mathrm{C}$, Z. mobilis was introduced on the solid medium and left for 2 days under $30^{\circ} \mathrm{C}$. The culture was reinoculated every 3 weeks and preserved at $4^{\circ} \mathrm{C}$. Final product from the cultivation was harvested by centrifugation (5000 g x $30 \mathrm{~min}$ ). Cell pellets were washed with distilled water and recentrifugated (16000 g x 20 $\mathrm{min})$. All cells were lyophilized and stored at $-20^{\circ} \mathrm{C}$ until being used.

\section{Lipid extraction}

In the literature lipid extraction from lyophilized cells were reported by using Bligh and Dyer method $^{12}$. However, Roth et $a l^{13}$ showed in their study the quantitative result comparison of lipids obtained from Bligh and Dyer method and from simple chlorophorm/methanol (96/4 $\mathrm{v} / \mathrm{v})$ extraction method. Results showed that BHT content was higher in the samples obtained from the chlorophorm/methanol (96/4 v/v) extraction method. Therefore, in our study we also used this extraction method to obtain BHT with higher efficiency. Fifty milliliters of chlorophorm/methanol (96/4 v/v) solvent mixture was used for each gr of cell. The mixture was stirred for $1 \mathrm{~h}$ at room temperature and then extracted lipids were collected by vacuum filtration (Whatman glass microfiber with a pore size of $1.6 \mu \mathrm{m}$ ).

\section{BHT identification in Z. mobilis}

BHT was separated from the extracted lipids using normal phase chromatography on a silica column (LiChrosorb 5-Si: 60, 10×250 mm). Analyses were achieved at ambient temperature 
with a flow-rate of $0.5 \mathrm{~mL} / \mathrm{min}$ and the following gradient profile was used as described before in the study of Moreau et al ${ }^{11} \mathrm{~A}: \mathrm{B}$ (95:5) 0-5 min; A:B (85:15) at $10 \mathrm{~min}$; A:B (40:60) at $15 \mathrm{~min}, \mathrm{~A}: \mathrm{B}: \mathrm{C}(40: 51: 9)$ at $53 \mathrm{~min}$ then isocratic to $68 \mathrm{~min}$; A:B (40:60) at $73 \mathrm{~min}$ and then $100 \%$ A from $78 \mathrm{~min}$ to $100 \mathrm{~min}$; where A:hexane, B:isopropanol C: $0.04 \%$ triethylamin containing water. BHT was identified at 20.03 min and its mass spectra was used to identify BHT in investigated lake sediments.

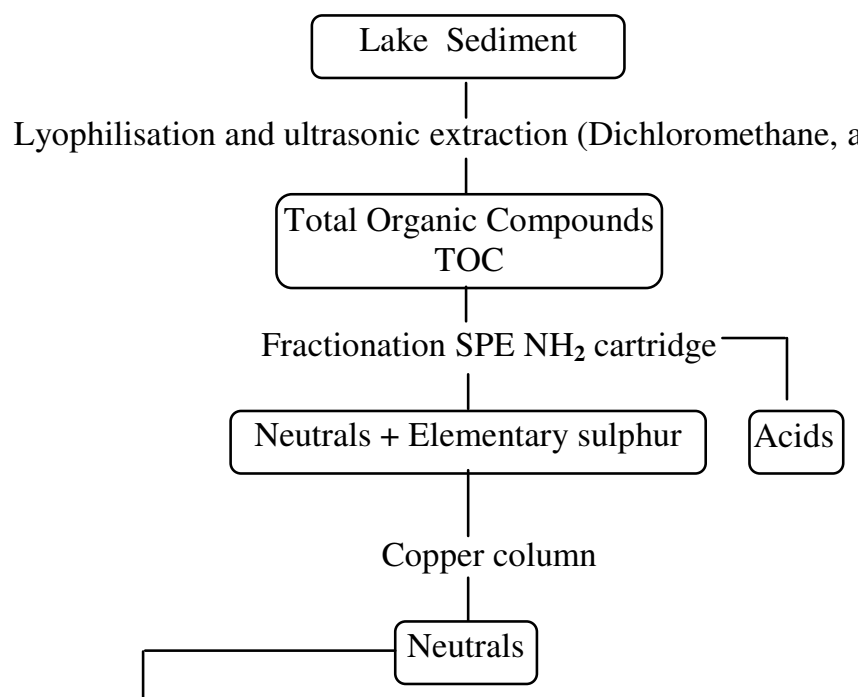

Flash chromatography on silica gel

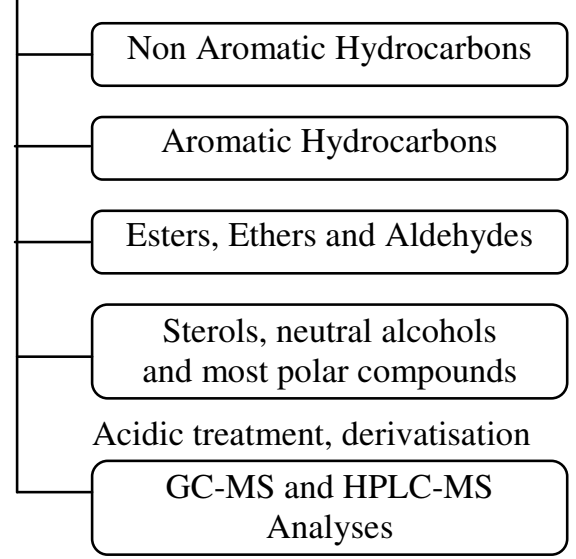

Figure 3. Sample preparation diagram

\section{LC-MS conditions}

The HPLC system comprised a Merck Hitachi L-6200A ternary solvent fitted with a Jones Chromatography Genesis C $18(150 \times 4.6$ mm, $4 \mu \mathrm{m}$ I.D. $)$ column and C $18(10 \times 4.6 \mathrm{~mm}, 4$ $\mu \mathrm{m}$ I.D.) guard column. Analyses were achieved at ambient temperature with a flow-rate of $1 \mathrm{~mL} / \mathrm{min}$ and with the following gradient profile: A:B (90:10) 0-5 min; A:B:C (40:1:59) at $45 \mathrm{~min}$, then isocratic to $70 \mathrm{~min}$; where A:MeOH, B:water and C:propan-2-ol. Samples were 
injected in $\mathrm{CH}_{2} \mathrm{Cl}_{2}$ with a $10 \mathrm{~mL}$ loop. The LC system was linked to a Finnigan MAT SSQ 7000 mass spectrometer via an APCI interface operated in positive ion mode. Conditions: vaporiser $400^{\circ} \mathrm{C}$; capillary $200^{\circ} \mathrm{C}$; corona $5 \mu \mathrm{A}$; capillary offset $5 \mathrm{~V}$ and nitrogen sheath gas pressure $60 \mathrm{psi}$. Data were recorded by scanning from $\mathrm{m} / \mathrm{z}, 185$ to 900 in $2 \mathrm{~s}$.

\section{$G C-M S$ conditions}

GC-MS analysis of the acetylated total extracts and periodic acid treatment products was conducted on a Hewlett-Packard $5890 \mathrm{GC}$ system (splitless injector, $315^{\circ} \mathrm{C}$ ) linked to a VG Masslab Trio 2 detector (interface temperature $300^{\circ} \mathrm{C}$; source temperature $210^{\circ} \mathrm{C}$; electron energy $70 \mathrm{eV})$. A DB5-HT column (30 m, $0.32 \mathrm{~mm}$ I.D.; $0.1 \mathrm{~mm}$ film thickness) was used with helium as the carrier gas. The oven temperature was programmed at $60^{\circ} \mathrm{C}$ (held for $1 \mathrm{~min}$ ), from 60 to $100^{\circ} \mathrm{C}$ at $10^{\circ} \mathrm{C} / \mathrm{min}$ and from 100 to $300^{\circ} \mathrm{C}$ at $5^{\circ} \mathrm{C} / \mathrm{min}$ (held for $35 \mathrm{~min}$ ). The mass spectrometer was operated in full scan mode $(\mathrm{m} / \mathrm{z} 50-900 ; 0.2 \mathrm{~s})$.

\section{Results and Discussion}

Analyses of sediment extracts (Lake Cadagno and Voua de la Motte) were achieved for the investigation of hopanoid biomarkers by using GC-MS and RP-HPLC-APCI-MS techniques. Biohopanoids were identified from their acetylated and periodic acid cleavage products. Mass chromatograms of the base peaks for BHT $\left[\left(\mathrm{M}+\mathrm{H}-\mathrm{CH}_{3} \mathrm{COOH}\right)^{+}=m / z\right.$ 655], the characteristic protonated molecule for aminotriol $\left[(\mathrm{MH})^{+}=\mathrm{m} / \mathrm{z} 714\right]$, aminotetrol $\left[(\mathrm{MH})^{+}=m / z\right.$ 772] and aminopentol $\left[(\mathrm{MH})^{+}=m / z\right.$ 830] were respectively identified for the anoxic sediment extracts of Lake Voua de la Motte and Lake Cadagno by RP-HPLC-APCIMS technique. On the other hand, hopanol $(a, m / z, 470)$, homohopanol $(b, m / z, 484)$ and bishomohopanol $(c, m / z 498)$ could be identified as the main periodic acid cleavage products of the investigated lake sediment extracts by GC-MS (Figure 4-6).

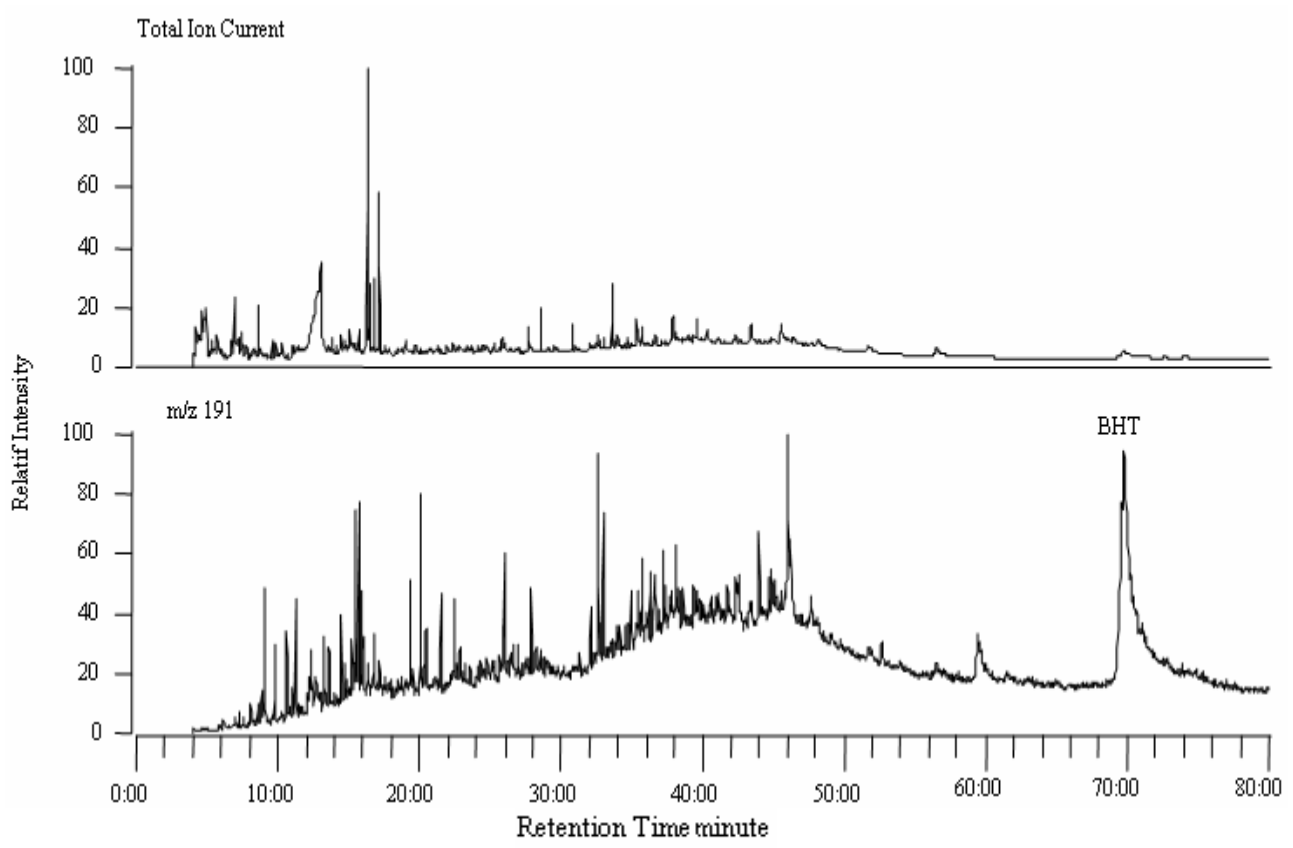

a) GC-MS analysis of acetylated extract. 


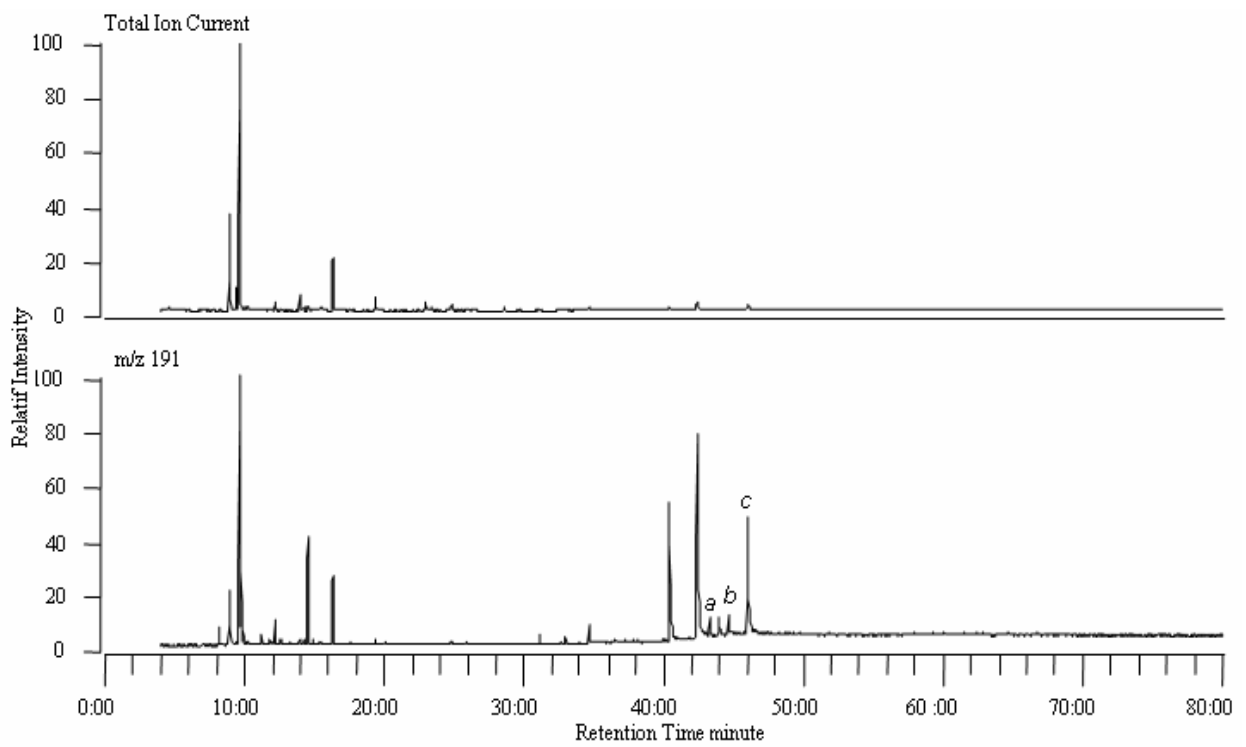

b) GC-MS analysis of periodic acid cleavage products
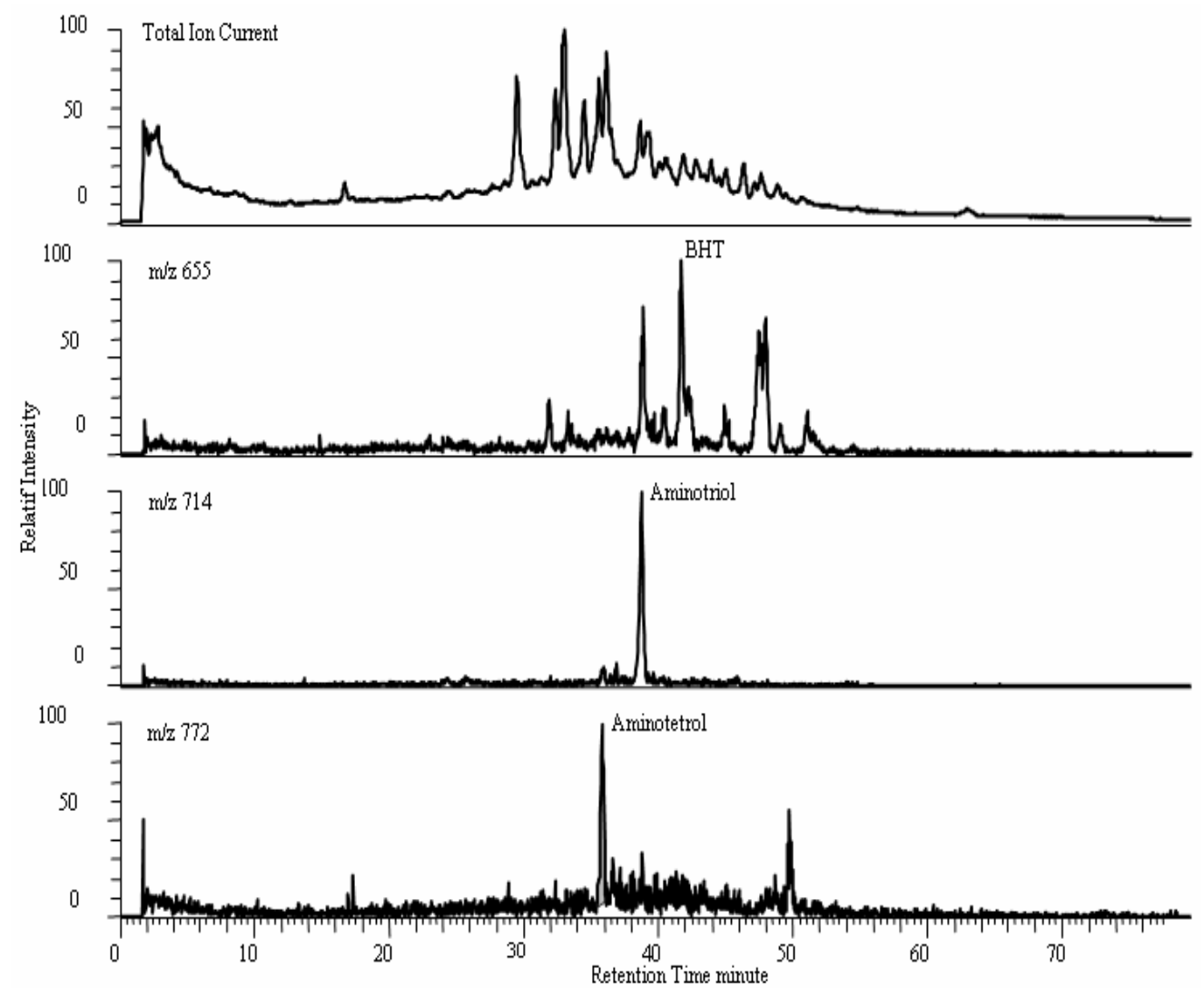

c) RP-HPLC-APCI-MS analysis of acetylated extract.

Figure 4. Lake Cadagno-anoxic zone analyses. 


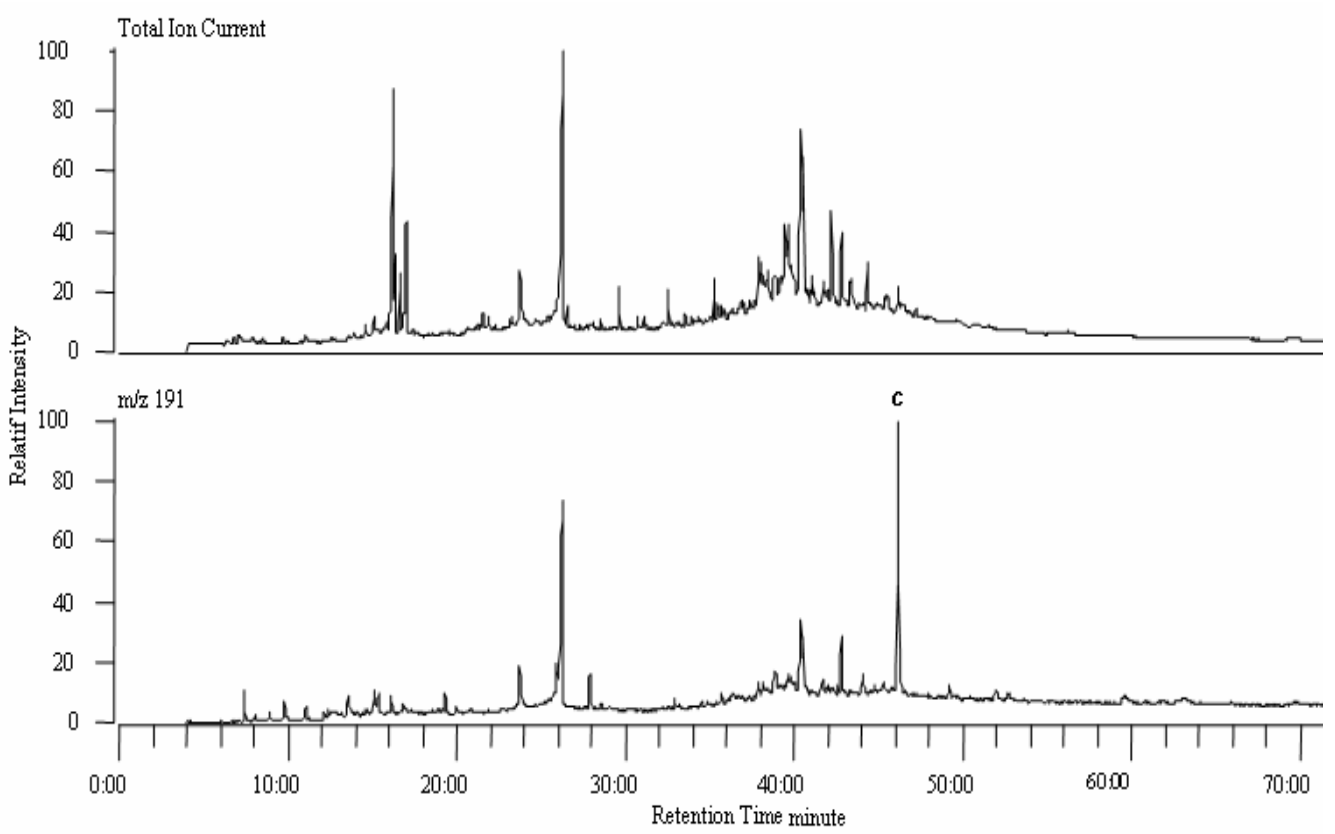

a) GC-MS analysis of acetylated extract

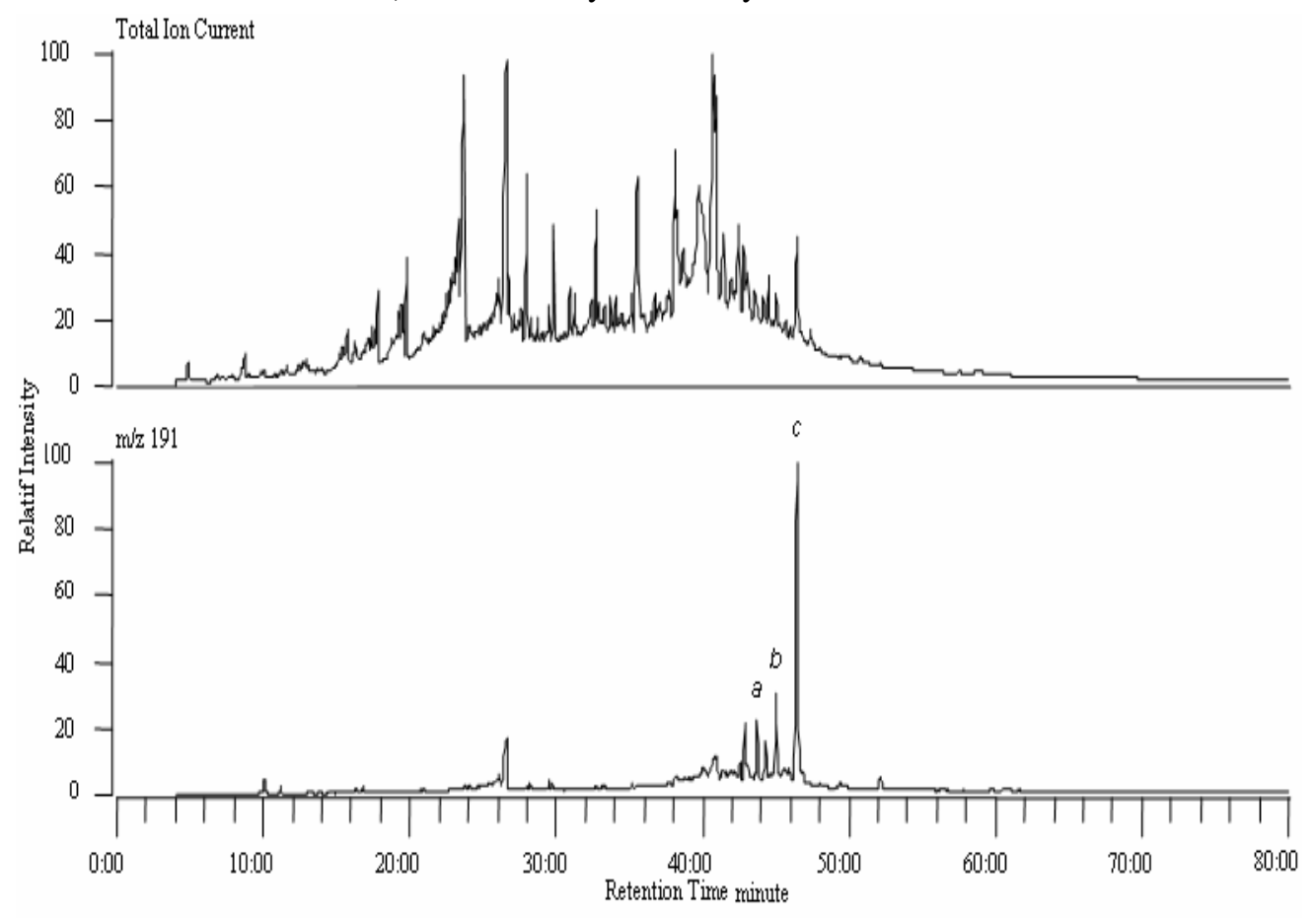

b) GC-MS analysis of periodic acid cleavage products. 


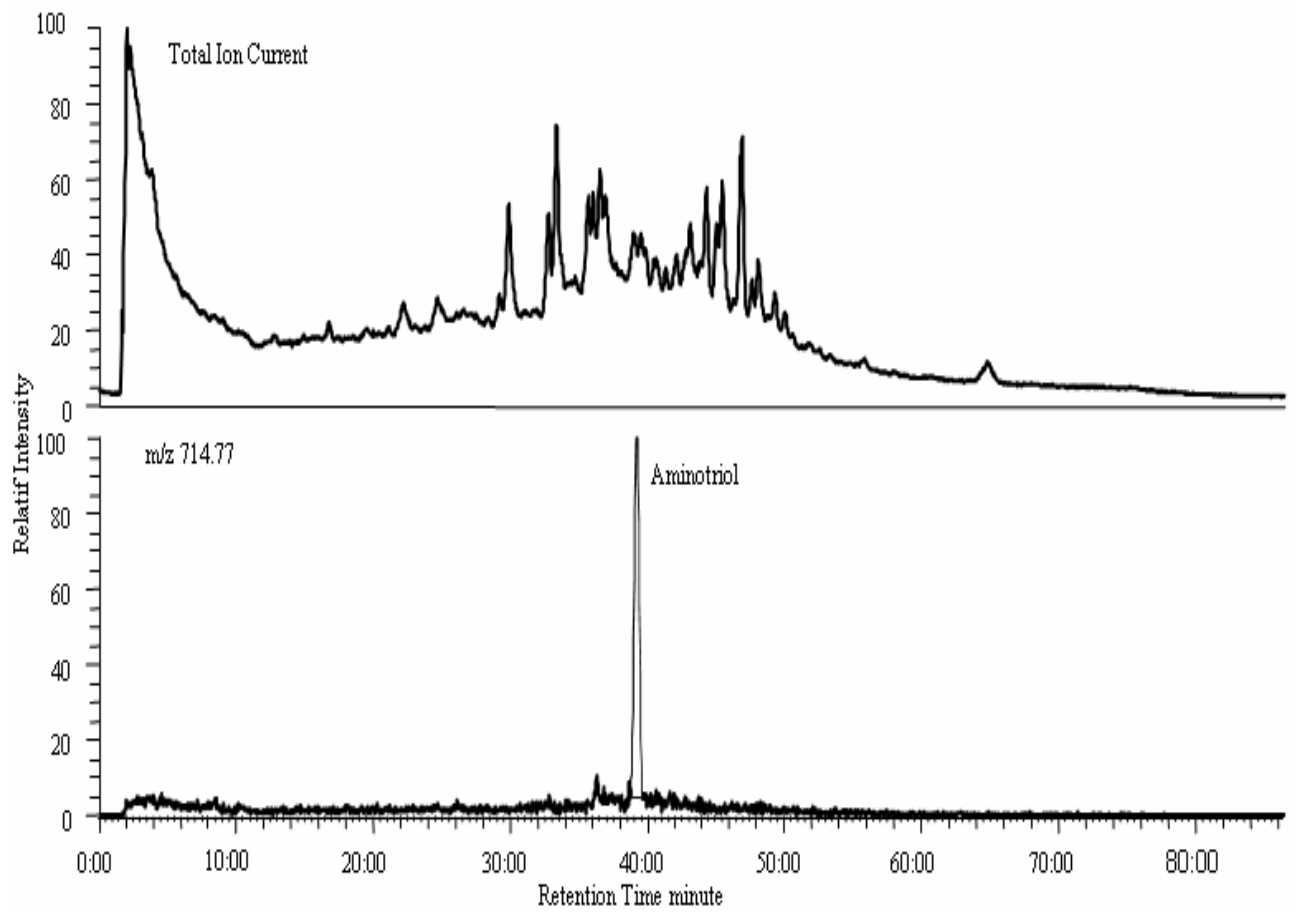

c) RP-HPLC-APCI-MS analysis of acetylated extract.

Figure 5. Lake Cadagno-oxic zone analyses

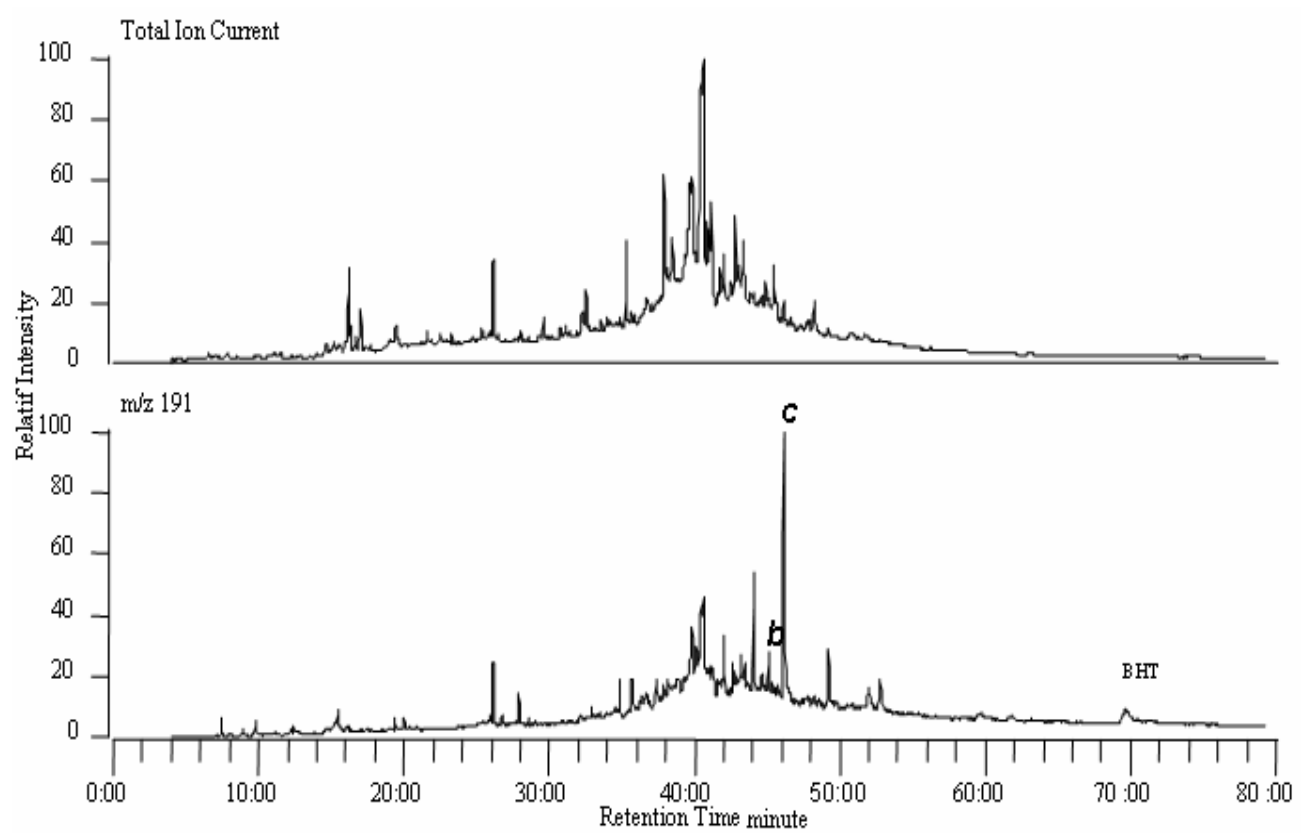

a) GC-MS analysis of acetylated extract. 


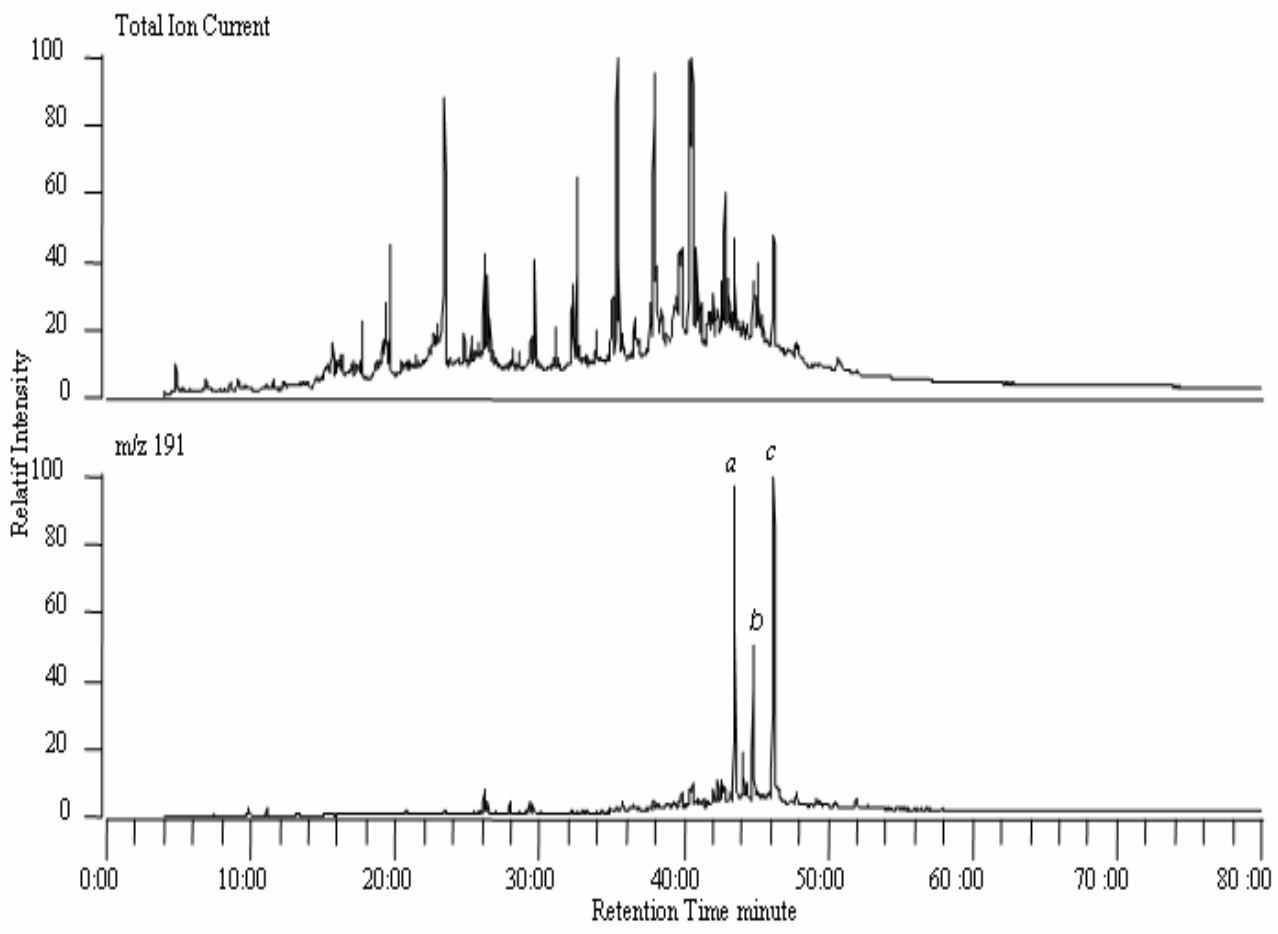

b) GC-MS analysis of periodic acid cleavage products

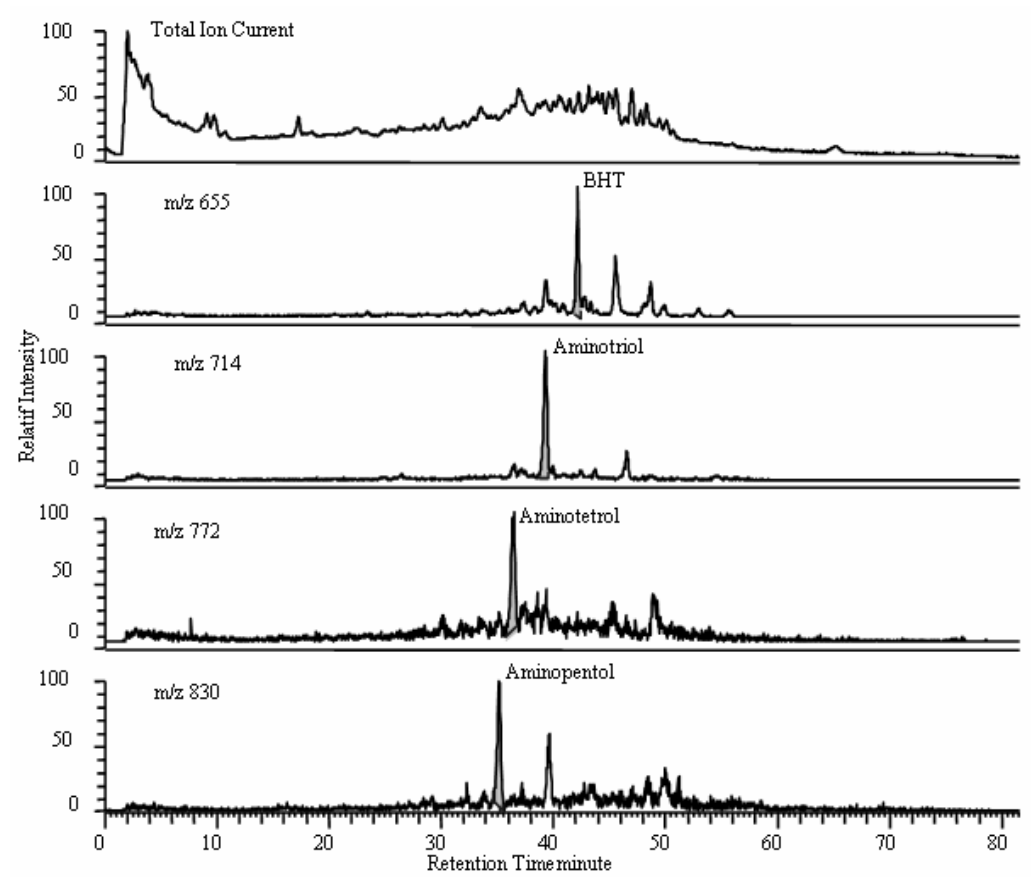

c) RP-HPLC-APCI-MS analysis of acetylated extract.

Figure 6. Lake Voua de la Motte-anoxic zone analyses. 
BHT, which is the most commonly reported BHPs from both cultured organisms, sediments and soils ${ }^{14-17}$, was found only in the samples from anoxic zones from both lakes. Neunlist and Rohmer ${ }^{18,19}$ showed that the existence of a group of BHPs with a $\mathrm{NH}_{2}$ group at C-35 is the excellent indicator of aerobic methane oxidizing bacteria in the sample. On the other hand, the hexafunctionalised side chain structure, aminopentol, is one of the most diagnostic, having been found only in Type I methane oxidizing bacteria ${ }^{20-22}$. Other $C$-35-amino BHPs, including the penta-functionalised compounds aminotetrol were shown in all methanotrophs as well as in trace amounts in some species of sulfate reducing bacteria (3) The tetrafunctionalised compound aminotriol, produced by all Type II methanotrophs, some Type I methanotrophs and a wide range of other organisms ${ }^{23}$ was present in all samples. Results showed that there is an environmental influence on sedimentary BHP distributions, with hexafunctionalised structures only being present in significant amounts in small, highly productive lake settings, as a result of methanogenesis and subsequent methanotrophy being significant processes in these eutrophic environments ${ }^{14,24}$. Hexafunctionalised hopanoids were reported in this study using the periodic acid method, which cleaves between adjacent diols, producing a primary alcohol which can be analysed using GC-MS ${ }^{10,14}$. The structure of the hopanol produced is directly indicative of the number of functional groups in the parent compound, so production of $\mathrm{a}_{30}$ hopanol indicates the presence of hexafunctionalised precursors. However, aminopentol was only found in samples from Lake Voua de la Motte anoxic zone. One possible explanation for this is that hexafunctionalised compounds other than the known aminopentol are contributing to the observed signal $^{23}$. This clearly demonstrates the importance of full structural characterisation, as previous detection of hexafunctionalised hopanoids via the periodic acid cleavage method has typically been interpreted as directly indicating an input from Type I methane oxidising bacteria $^{14,24}$. Therefore, the results emphasize the need for more studies on an even wider range of environmentally significant bacterial species.

\section{Conclusion}

The distributions of hopanol (a) and homohopanol (b) were found quite similar in the sediment samples obtained from oxic and anoxic zone of Lake Cadagno but bishomohopanol (c) was found relatively higher in the samples from oxic zone. On the other hand the distributions of hopanol (a) and homohopanol (b) in the samples obtained from Lake Voua de la Motte were found relatively higher than the samples from Lake Cadagno. As can be seen from the Figures; BHT could only be identified in the samples from the anoxic zone of the lakes.

\section{Acknowlegements}

The author would like to thank Prof. F. Gülaçar (University of Geneva, Laboratory of Mass Spectrometry, Geneva, Switzerland) for the opportunity to use all instrumental facilities for this research, Dr. Houot for the sample preparation stage, Mr. Kloeti, Mr. Perrottet and Mr. Biondina for the sampling.

\section{References}

1. Ourisson G, Rohmer M and Poralla K, Ann Rev Microbiol., 1987, 41, 301-333.

2. Rohmer M, Pure Appl Chem., 1993, 65(6), 1293-1298.

3. Blumenberg M, Krüger M, Nauhaus K, Talbot H M, Oppermann B I, Seifert R, Pape T and Michaelis W, Environ Microbiol., 2006, 8(7), 1220-1227.

4. Finck Y, Aydin N, Pellaton C, Gorin G and Gülaçar F, J Chromatogr A., 2004, 1049(1-2), 227-231. 
5. Schüpfer P, Finck Y, Houot F and Gülaçar F O, Org Geochem., 2007, 38(4), 671-681.

6. $\quad$ Daher S and Gülaçar F, Arch Sci., 2005, 58(1), 25-42.

7. Aydin N, Daher S and Gülaçar F O, Chemosphere, 2003, 52(5), 937-942.

8. Riffe-Chalard C, Verzegnassi L and Gülaçar F O, Geochem., 2000, 31(12), 1703-1712.

9. Verzegnassi L, Riffe-Chalard C, Kloeti W and Gülaçar F O, Fresen J Anal Chem., 1999, 364(3), 249-253.

10. Innes H E, Bishop A N, Head I M and Farrimond P, Org Geochem., 1997, 26(9/10), 565-576.

11. Moreau R A, Powell M J, Osman S F, Whitaker B D, Fett W F. Roth L and O'Brien D J, Anal Biochem., 1995, 224(1), 293-301.

12. Bligh E G and Dyer W J, Can J Biochem Physiol., 1959, 37, 911-917.

13. Roth L H, Moreau R A, Powell M J and O'Brien D J, Anal Biochem., 1995, 224(1), 302-308.

14. Talbot H M, Watson D F, Pearson E J and Farrimond P, Org Geochem., 2003, 34(10), 1353-1371.

15. Talbot H M, Farrimond P, Schaeffer P and Pancost R D, Org Geochem., 2005, 36(4), 663-672.

16. Talbot H M, Summons R. E, Jahnke L L, Cockell C S, Rohmer M and Farrimond P, Org Geochem., 2008, 39(2), 232-263

17. Coolen M J L, Talbot H M, Abbas B A, Ward C, Schouten S, Volkman J K and Sinninghe Damsté J S, Environm Microbiol., 2008, 10(7), 1783-1803.

18. Neunlist S and Rohmer M, J Gen Microbiol., 1985, 131(6), 1363-1367.

19. Neunlist S and Rohmer M, Biochem J, 1985, 231(3), 635-639.

20. Neunlist S, Holst O and Rohmer M, Eur J Biochem., 1985, 147(3), 561-568.

21. Zhou P, Berova N, Nakanishi K, Knani M and Rohmer M, J Am Chem Soc., 1991, 113(10), 4040-4042

22. Cvejic J H, Bodrossy L, Kovacs K L and Rohmer M, FEMS Microbiol Lett., 2000, 182(2), 361-365

23. Talbot H M and Farrimond P, Org Geochem., 2007, 38(8), 1212-1225

24. Farrimond P, Head I M and Innes H E, Geochim Cosmochim Acta, 2000, 64(17), 2985-2992. 


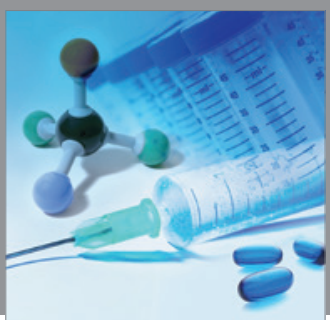

International Journal of

Medicinal Chemistry

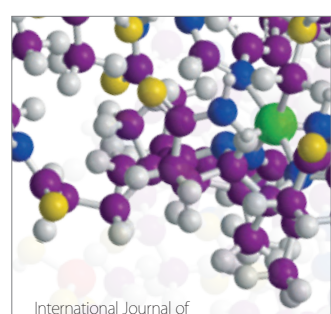

Carbohydrate Chemistry

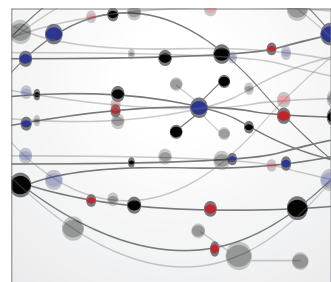

The Scientific World Journal
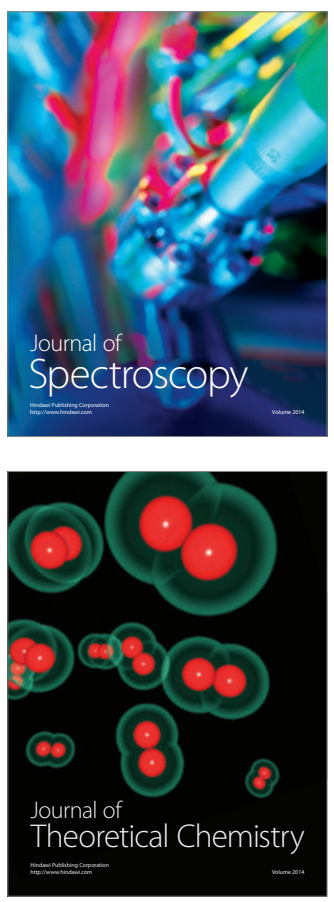
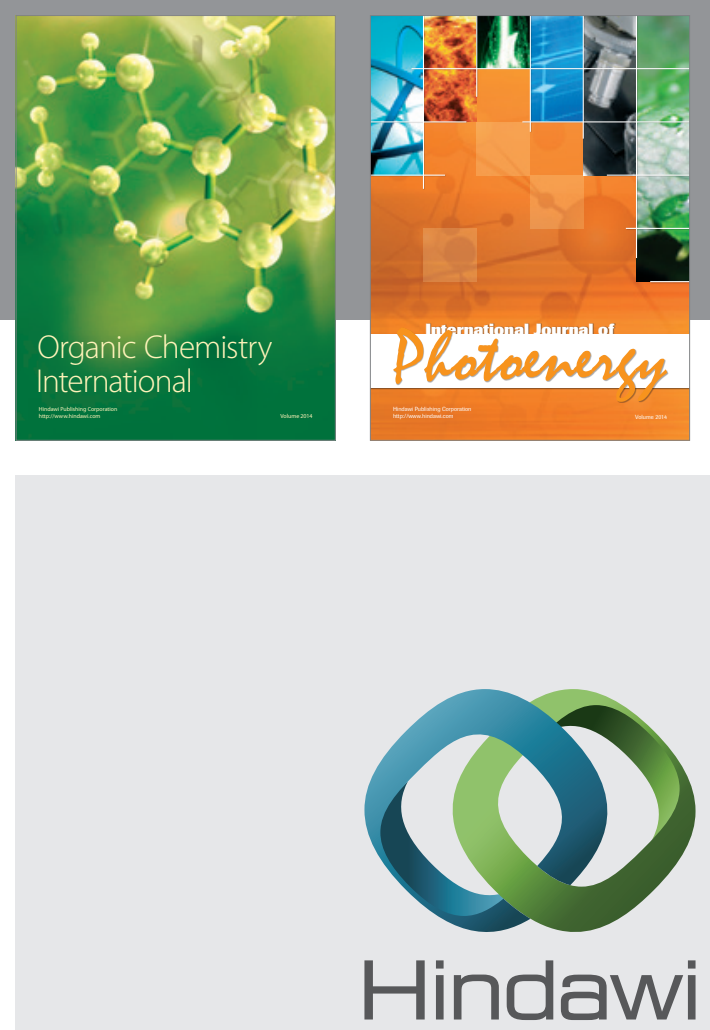

Submit your manuscripts at

http://www.hindawi.com
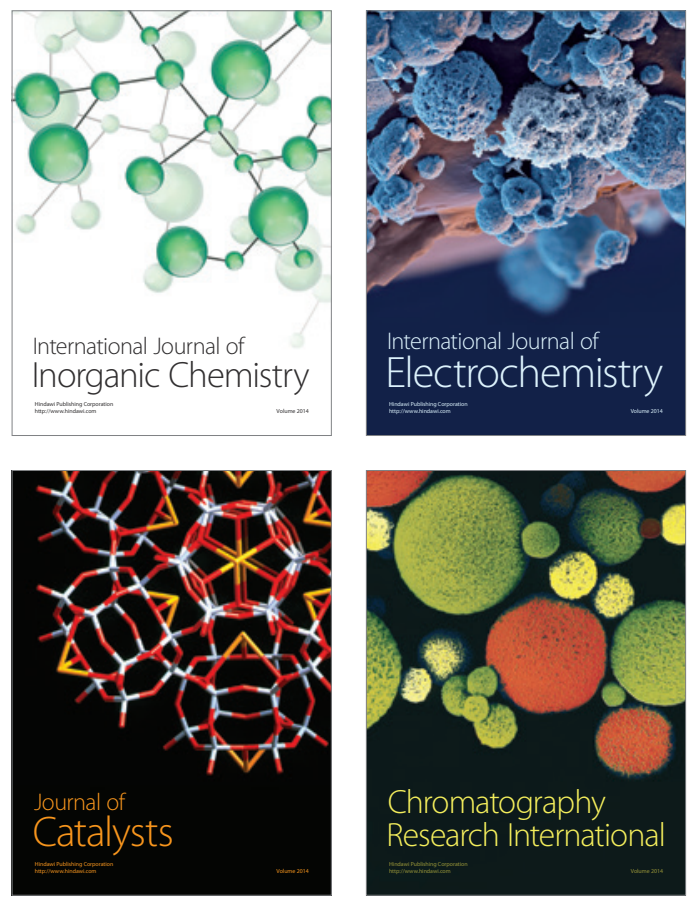
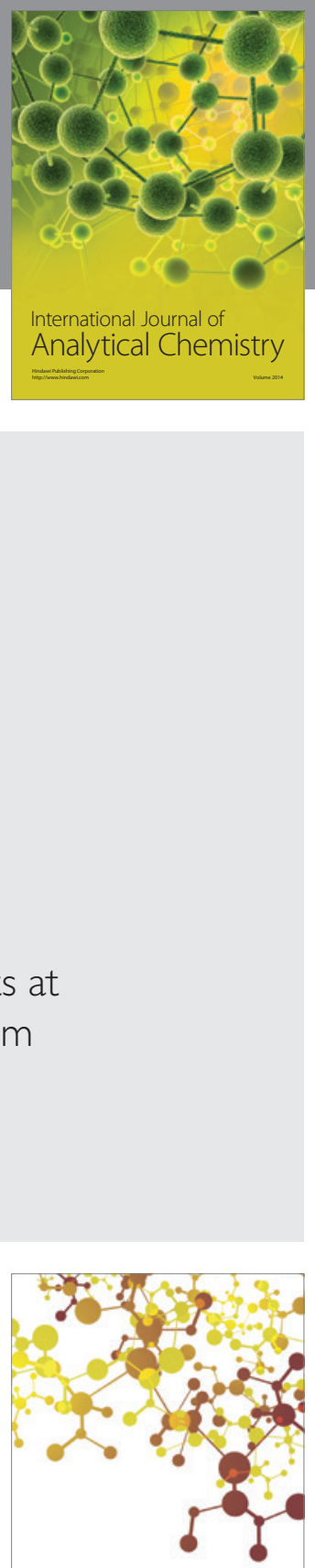

Journal of

Applied Chemistry
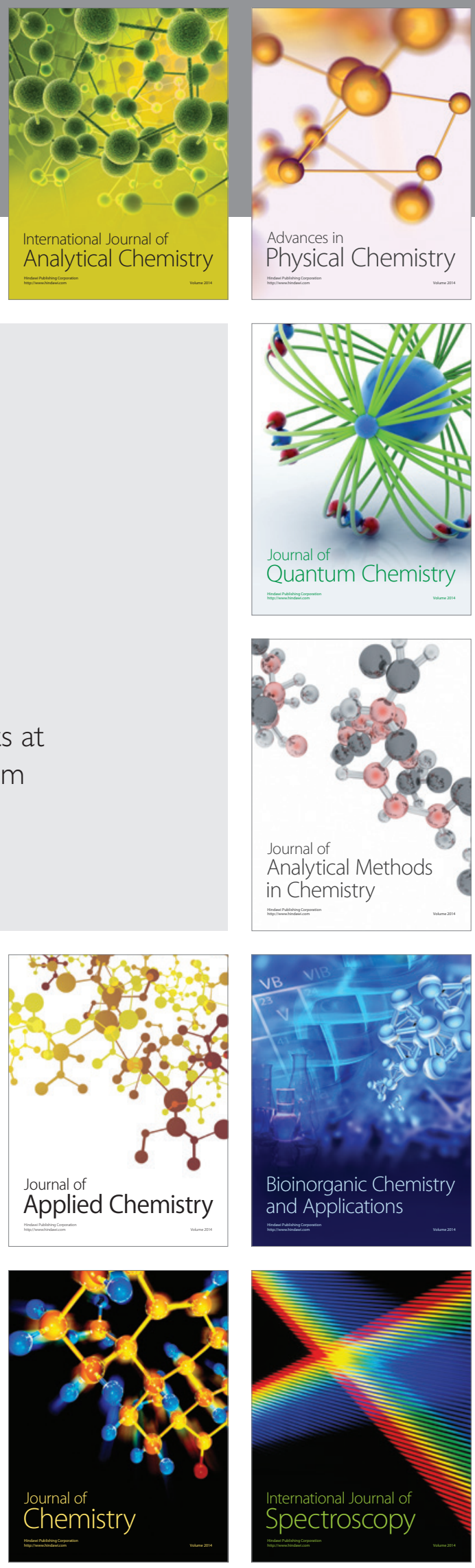